\title{
Evaluation of tectonic activity using morphometric indices: case study of the Tatra Mts. (Western Carpathians, Poland)
}

\author{
Krzysztof Buczek ${ }^{1}$ (D) . Marek Górnik ${ }^{1}$
}

Received: 22 August 2019 / Accepted: 25 March 2020 / Published online: 7 April 2020

(c) The Author(s) 2020

\begin{abstract}
The Tatra Mountains (Tatra Mts.) are the highest and most glacially reshaped mountain massif in the Carpathians. Previous studies suggested the tectonic uplift of this massif along the large sub-Tatric fault during Quaternary. The main goal of this paper is to characterise the tectonic activity in the Tatra Mts. using 6 geomorphic indices for 78 drainage basins: the streamgradient index (SL), asymmetry factor (Af), basin shape ratio (Bs), hypsometric integral (Hi), valley floor width-valley height ratio (Vf), as well as mountain-front sinuosity (Smf). These parameters were combined in order to obtain the relative tectonic activity index (Iat) using GIS. The average of the six computed geomorphic indices was used to evaluate the distribution of relative tectonic activity in the study area. According to Iat values, four classes of different tectonic activity can be distinguished in the Tatra Mts.: class 1 of very high tectonic activity ( $0.7 \%$ of Tatra Mts.); class 2 of high activity (24.3\%); class 3 of moderate activity (68.4\%); and class 4 of low activity (6.6\%). Our study confirmed previous suggestions about unequal uplift of different parts of the massif. Iat values show high tectonic activity along the Sub-Tatric fault, as well as in the northern part of the Belianskie Tatra. Distribution of $\mathrm{Vf}$ and Hi values correlate with extend of glaciers during Last Glacial Maximum. It seems that values of some geomorphic indices, such as Vf and HI, are strongly associated with glacial reshaping of the Tatra Mts. during the Pleistocene.
\end{abstract}

Keywords Relative tectonic activity · Carpathians · Tatra Mts. · Geomorphic indices · Tectonic uplift

\section{Introduction}

Present-day topography of mountain ranges is a result of interaction between tectonic and erosional processes (Bishop 2007). Geomorphological analysis of mountain fronts provides substantial clues to the reconstruction of tectonic activity of range-bounding faults in variable timescales $\left(10^{3}-10^{6}\right.$ years; Burbank and Anderson 2001; Keller and Pinter 2002; Bull 2007; Demoulin et al. 2015). Numerous studies have shown high utility of drainage basin-scale morphometric analyses to evaluate tectonic activity (Bull and McFadden 1977; Azor et al. 2002; Keller and Pinter 1996, 2002; Silva et al. 2003; Dehbozorgi et al. 2010; Matoš et al. 2016). Various morphometric indices can be combined, especially using geographic information systems (GIS) to

Krzysztof Buczek

buczek@iop.krakow.pl

1 Institute of Nature Conservation, Polish Academy of Sciences, Adama Mickiewicza Ave. 33, 31-120 Kraków, Poland obtain summary index of relative tectonic activity (El Hamdouni 2008; Dehbozorgi et al. 2010; Mahmood and Gloaguen 2012; Matoš et al. 2016; Ntokos et al. 2016). One of the most popular methods used to evaluate tectonic activity was proposed by El Hamdouni (2008). The index of relative tectonic activity (Iat) was used in various, tectonically active regions: Sierra Nevada Mts. (El Hamdouni 2008), northern Iran (Alaei et al. 2017), central Alborz (Bagha et al. 2014), central Zagros (Dehbozorgi et al. 2010), High Zagros (Arian and Aram 2014; Eshani and Arian 2015), and Tibetan Plateau (Chang et al. 2015).

This study focused on the Tatra Mts. area, located in northwestern part of the Carpathian orogenic system. Although low-temperature chronology indicates early and middle Miocene rapid exhumation of the study area (Śmigelski et al. 2016), recent relief and elevation of Tatra Mts. could be a result of tectonic uplift during Quarternary (Králiková et al. 2014). Uneven tectonic uplift of the Tatra Mts. during the Quaternary period was noticed by many authors (Klimaszewski 1988; Lukniš 1973; Bac-Moszaszwili 1995; Jurewicz 2005). The tectonic uplift of this massif 
was connected with oblique and unequal tectonic movement along the Sub-Tatra fault as well as activation of transversal fault systems (NE-SW) (Piotrowski 1978; Jurewicz 2005). Tectonically deformed cave passages are also considered as a manifestation of young (Eemian or younger) fault activity in the Tatra Mts. (Szczygieł 2015). Late Quaternary activity of located south of Tatra Mts. Vikarovce fault was confirmed by luminescence dating (Vojtko et al. 2011). The studies of historical earthquakes suggest moderate seismic activity of Western Carpathians including the Tatra Mts. (Kováč et al. 2002). Major concentrations of shallow crustal earthquakes were noticed around the Tatra massif, on the area of the Central Carpathian Paleogene Basin and along the Prosčné fault (Hók et al. 2016).

Repeated precise levelling measurements (Makowska and Jaroszewski 1987), as well as PSInSAR (Persistent Scatterers SAR Interferometry Analysis) (Perski 2008), indicate a varied uplift of the Tatra Mts. and Pieniny Klippen Belt, and a subsidence of the Orava Basin situated in between these units. According to these studies, a recent relative uplift rate of the northern margins of the Tatra Mts. compared to Orava Basin is estimated at $0.995 \mathrm{~mm} / \mathrm{a}$ (Perski 2008). The rate of recent tectonic uplift on the northern margins of the Tatra massif is $0.3 \mathrm{~mm} / \mathrm{a}$. Previous research on southern borders of the study area suggested that the recent uplift rate ranges 3-8 mm/a (Hradilec et al. 1981); however, these values seem to be overestimated (Łój et al. 2009).

This paper aims to evaluate the tectonic activity in the highest mountain massif in the Carpathians: Tatra Mountains, based on selected geomorphic indices and relative tectonic activity index (Iat).

\section{Study area}

The Tatra Mts. form the highest mountain massif in the Carpathian Orogenic Belt (Central Western Carpathians), with the highest peak being Mt. Gerlachovski Štit, which stands at $2655 \mathrm{~m}$ a.s.l. This confined mountain area, situated along on the Poland-Slovak border, covers ca. $785 \mathrm{~km}^{2}$ (Fig. 1a and b). The differences in rock lithology and amplitude of relief resulted in the division of this highly confined mountain area into three parts: High Tatra Mountains, Western Tatra Mountains, and Belianskie Tatra (Fig. 1c). The mountain ranges of the Western Tatra Mts., with the highest peak of Mt Bystrá (2250 m a.s.1.), are usually several hundred metres lower than the High Tatra.

The structural/geological core of the studied massif is formed of Tatric crystalline basement composed of two Variscan tectonic units: metamorphic sequences of the Western Tatra Mts. (gneisses, schists) and granitoid rocks of the High Tatra Mts. (Janák 1994; Lexa et al. 2000) (Fig. 2b). The crystalline core was overlain by Mesozoic sedimentary rocks belonging to three structural elements: autochthonous cover, which was overthrust by the HighTatric Nappes, and Sub-Tatric Nappes: Choč and Križna. Both Variscan and Mesozoic units were transgressively covered by carbonates of so-called Nummulitic Eocene and post-orogenic Paleogene flysch (Lexa et al. 2000; Jurewicz 2005).

The Tatra Mts. form an asymmetrical horst-like structure surrounded by Central Carpathian Paleogene Basin (CCPB) divided into a few sub-basins (Fig. 2a): Orava Basin, Podhale Basin, Levoca Basin, and Liptów Basin (Nemčok et al. 1993). Neogene uplift of the Tatra block along the Sub-Tatra fault (southern margins of massif) caused tilting of autochthonous cover and overthrust of the High-Tatric and Sub-Tatric Nappes toward the north (Sokołowski 1959). The uplift had rotational, counterclockwise character where the rotational axis was horizontal and W-E oriented (Piotrowski 1978; Jurewicz 2005). Thermochronological data indicate rapid exhumation of the Tatra massif during early and mid-Miocene (Śmigelski et al. 2016). Next acceleration of tectonic activity occurred during Pliocene to Pleistocene (Vojtko et al. 2011) or latest Late Miocene to Pleistocene (Králiková et al. 2014). It is considered that the Prosečné, Sub-Tatra, and Ružbachy faults which separate horst-like structure of the Tatra Mts. from the Central Carpathian Paleogene Basin, operated as normal faults during the neotectonic stage (Nemčok et al. 1993; Králiková et al. 2014). Tectonically deformed cave passages in Tatra Mts. strongly indicate fault activity during Quaternary. U-series dating of speleothems point to Eemian or younger age of the displacements (Szczygiel 2015). Existence of calcareous tufa and travertine mounds along the northern and southern borders of Tatra Mts. was also considered as a manifestation of tectonic activity during Quaternary (Králiková et al. 2014). Late Quarternary activity of Vikarovce fault which is parallel to Sub-Tatra fault was proved by luminescence datings. Average slip rate along Vikarovce fault was estimated at $0.8-1.0 \mathrm{~mm} / \mathrm{a}$ (Vojtko et al. 2011).

During the Last Glacial Maximum (LGM), about 35.6\% of the entire mountain area was covered by glaciers (Zasadni et al. 2014; Kłapyta et al. 2016). From among 78 selected drainage basins, 48 had glaciers at that time. The High Tatra Mts. was the most glaciated part of the study area with many glaciers descending below the mountain front (Zasadni et al. 2014). The Western Tatra was less affected by glaciers where only two glaciers were located on the southern slopes (Kamenistá Valley Glacier and Bystrá Valley Glacier) extending beyond the mountain front. In the Belianske Tatra, there was only minor landscape transformation by small cirque-type glaciers (Zasadni et al. 2014). 

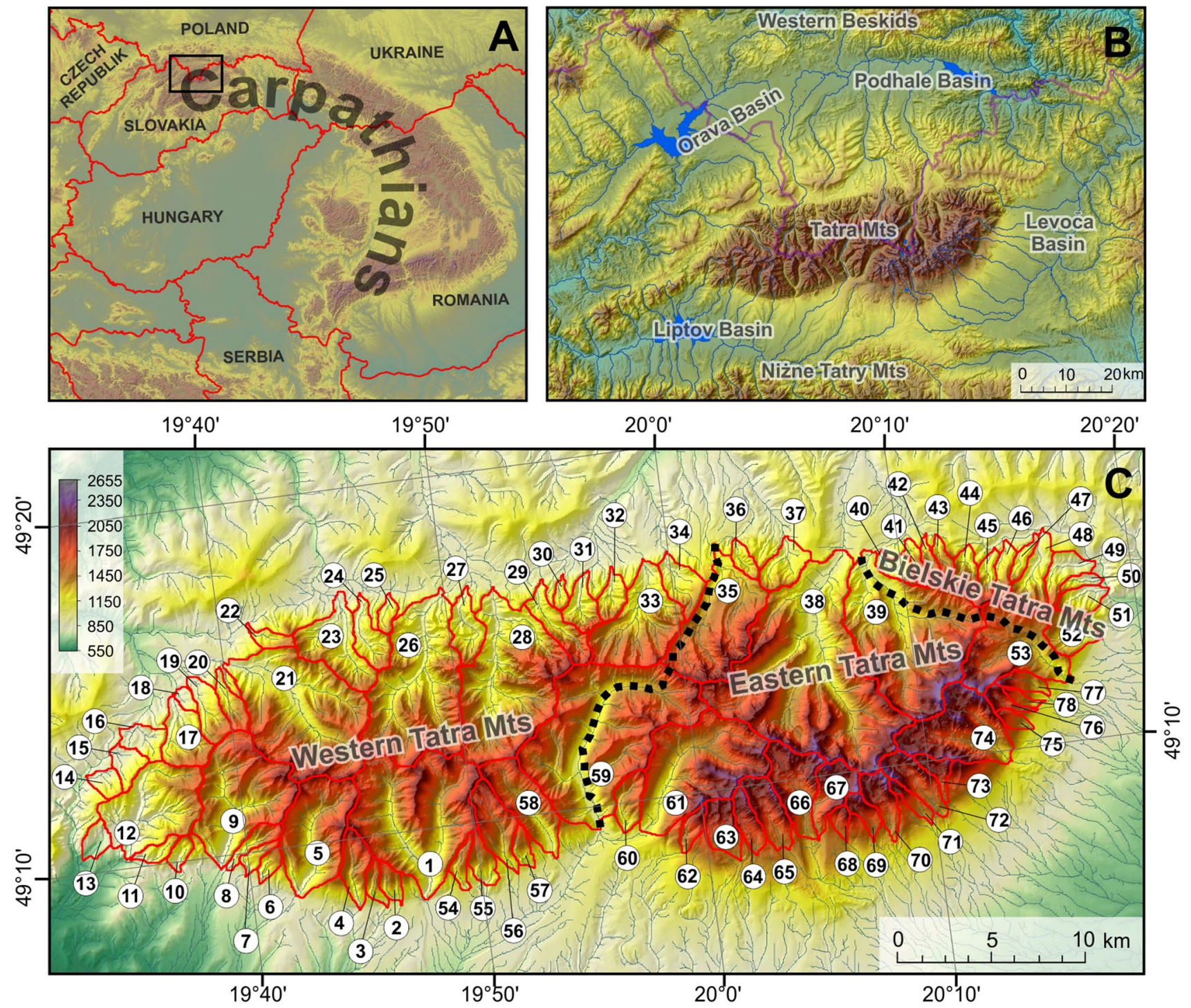

Fig. 1 Location of the Tatra Mts. in the Carpathians (a and b) and their morphological division (black dashed lines) (c). Number (1-78) indicates the selected basins

\section{Morphometric analysis and results}

In this research, several morphometric indices are used to analyse the degree of tectonic activity in the area of the Tatra Mts. The indices selected for this analysis are Stream length—gradient index (SL), Hypsometric Integral (HI), Asymmetric factor (Af), Basin shape index (Bs), Ratio of valley floor width to valley height (Vf), and mountain front sinuosity (Smf) (e.g. Pike and Wilson 1971; Hack 1973; Bull and McFacdden 1977; Bull 1978; Hare and Gardner 1985; Keller and Pinter 2002). Finally, a single index (Iat) was calculated from these six indices for every drainage basin (El Hamdouni et al. 2008). EU-DEM Digital Surface Model (DSM) with a resolution of $25 \mathrm{~m}$ was downloaded from https://www.eea.europa.eu/data-and-maps/data/ eu-dem. All mentioned morphometric parameters for 78 sub-basins in the Tatra Mts. were analysed using ArcGIS software.

\section{Stream-gradient index (SL)}

This parameter is highly sensitive to the change in channel slope caused by rock resistance or tectonic activity. Many studies have connected high values of SL index with tectonic uplifting. Contrarily, low values can be related to stable or subsiding areas or when streams flow through strike-slip faults. (Keller and Pinters 2002; Chen et al. 2003; Troiani et al. 2008; El Hamdouni et al. 2008). SL index was calculated using Hack Eq. (1973): 


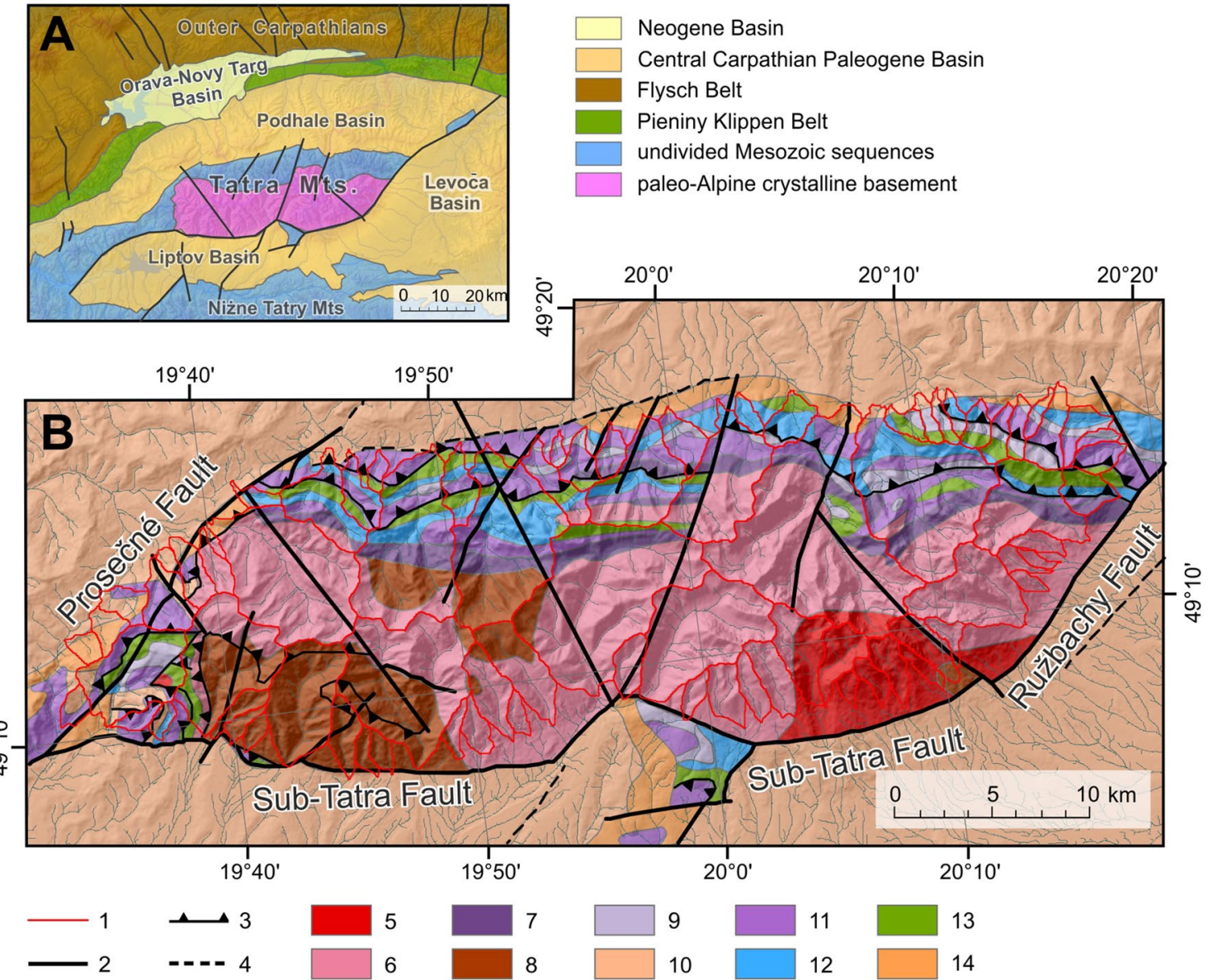

Fig. 2 Simplified geological scheme of Tatra Mts. and surrounding area (a) and geological map of Tatra Mountains (b): 1. drainage lines; 2 . faults; 3 . thrusts; 4 . possible faults; 5 . tonalite and granodiorite; 6. granite; 7. quartzite, sandstone, and shale; 8. amphibolite, migmatite, and gneiss; 9. shale, sandstone, limestone, dolomite; 10. con-

$S l=(\Delta h / \Delta l) l$,

where $\Delta h$ is a variation of elevation, $\Delta l$ is a length of the segment, and $l$ is horizontal length from divide to the midpoint of the segment where the index is calculated. To discriminate SL index values related to rock resistance, a qualitative map of rock strength based on rock type was prepared. In this paper, we define four levels of rock resistance: low (variegated shales, claystones), moderate (marls, thin-bedded flysch), high (metamorphic rocks, limestones, dolomites, conglomerates), and very high resistance (granitic rocks). Map of rock resistance is shown in Fig. 3.

The SL value is classified into three classes: class 1 (SL $>500)$, class $2(300<\mathrm{SL}<500)$, and class 3 (SL < 300) (El Hamdouni et al. 2008). The maximum average value was 527.5 (basin 71) on the southern slopes of the High Tatra Mts. and the minimum was 118.6 (basin glomerate, sandstone, marlstone, shale; 11. limestone and dolomite; 12. limestone, sandstone, sandstone-limestone; 13. carbonate claystone and marlstone; 14 . conglomerate, sandstone, limestone, breccia, and claystone rocks (after Lexa et al. 2000)

17) on the northern slopes of the Western Tatra Mts. (Fig. 4a). The majority of the study area belongs to the second SL class (ca. 89\%). The lowest values (class 3) occurred on the northern and western flanks of the massif (ca. 14\%).

High values of SL index in southern slopes of the High and Western Tatra Mts. can be related to the very high rock resistance of granites, granodiorites, and metamorphic rocks which build up this part of the study area, as well as with tectonic activity of the Sub-Tatra fault (Fig. 3, Fig. 4b). High values of the indices on outcrops of moderately resistant rocks can be seen on the NE flank of the Belianskie Tatra Mts. These values can be also associated with tectonic activity. A few higher values of SL located on the northern slopes of the High and Western Tatra Mts. (Figs. 3, 4b) are related to changes in rock resistance (e.g. contact of dolomites and shales). 


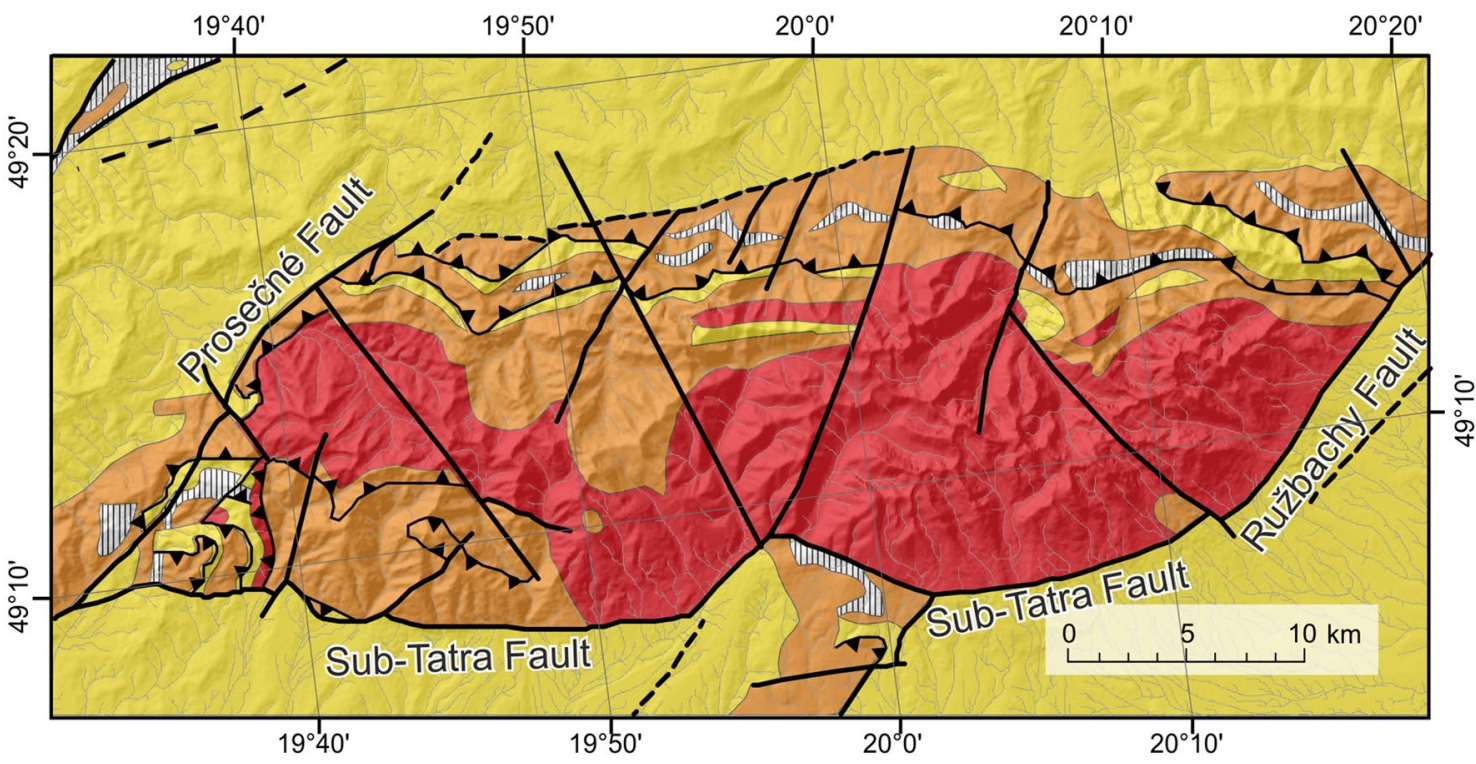

Rock strenght levels:

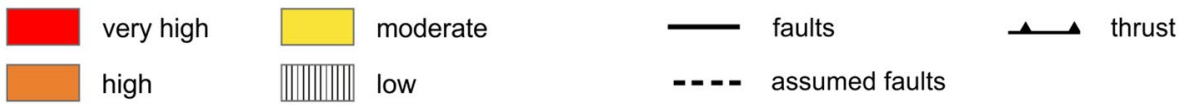

Fig. 3 Distribution of rock strength levels (after Lexa et al. 2000)

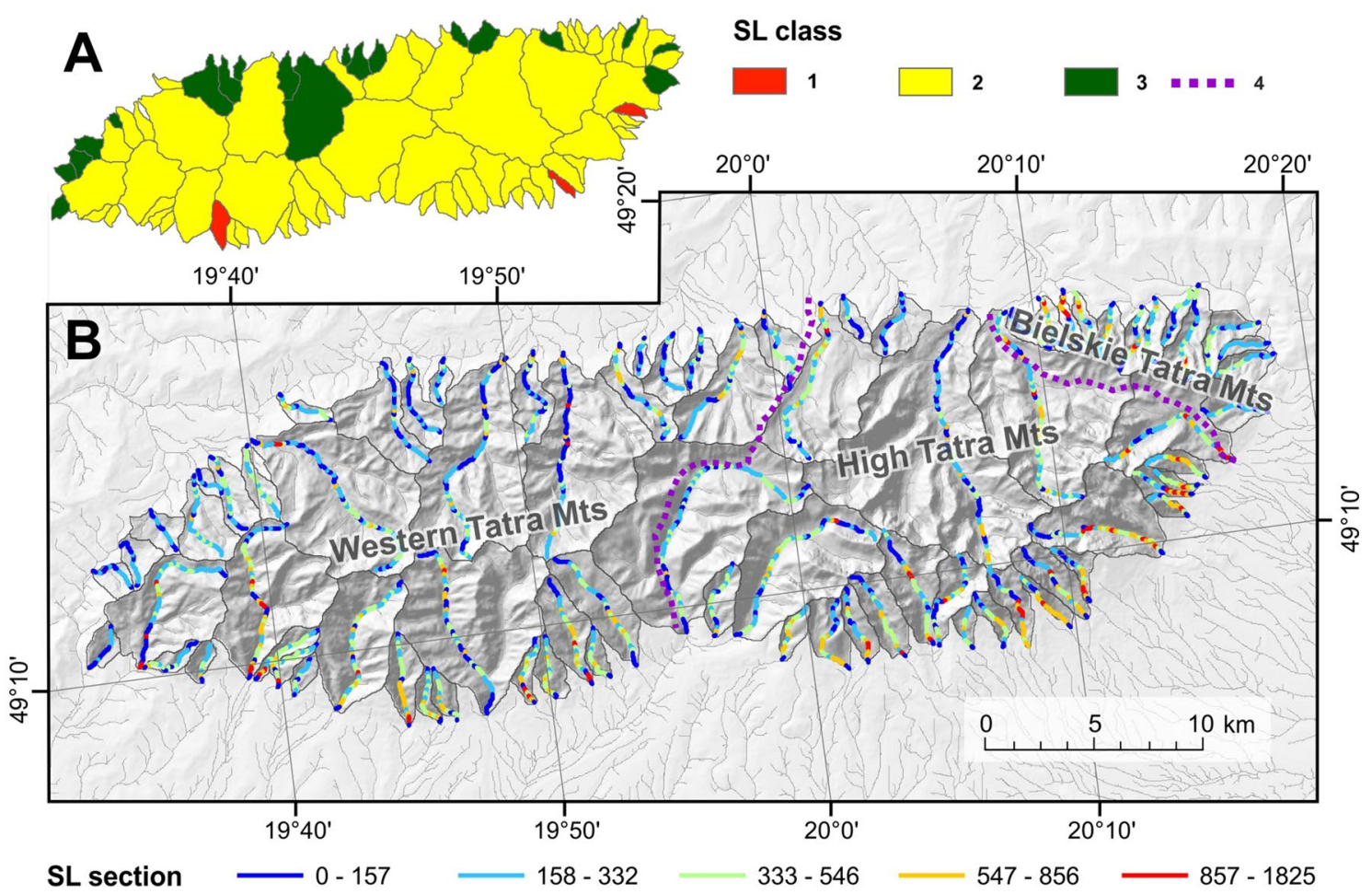

Fig. 4 Distribution of SL index classes in selected basins (a) and SL index along drainage network in the Tatra Mts. (b) dashed lines mark geographic boundaries dividing the Tatra Mountains into three geographic regions 


\section{Asymmetry factor (Af)}

Asymmetry factor (Af) was used to evaluate possible tectonic tilting at the basin-scale. Hare and Gardner (1985) define this parameter as

$\mathrm{Af}=\left(\frac{\mathrm{Ar}}{\mathrm{At}}\right) \times 100$

where $\mathrm{Ar}$ is the area to the right side of the catchment (facing downstream of the trunk stream) and At is the total area of basin. These calculations were categorized into three classes: 1 (Af $\geq 68) ; 2(55 \leq \mathrm{Af}<68$ or $21 \leq \mathrm{Af}<42)$; and 3 (42 $\leq$ Af $<55)$ (El Hamdouni 2008). For the purpose of expressing the tilting direction of basins in the Tatra Mts., we calculated the Af parameter as its absolute value minus 50. Added arrows indicate the asymmetry direction in Fig. 5b:

Af $=\left[50-\frac{\operatorname{Ar} \times 100}{\mathrm{At}}\right]$.

Absolute Af values were divided into four classes: $\mathrm{Af}<5$ (symmetric basins), Af $=5-10$ (gently asymmetric basins),
Af $=10-15$ (moderately asymmetric basins), and Af $>15$ (strongly asymmetric basins) (Pérez-Peña et al. 2010).

In the study area, the Af varies from 18.7 (basin 15) to 79.9 (basin 23). About $11.5 \%$ of selected basins are characterized by strong asymmetry ( 1 Af class). More than half of the basins (53.8\%) belong to the second Af class (Fig. 5a). Absolute values of asymmetry can be used to show probable large-scale tilting in the Tatra Mts. Generally, drainage basins on the southern and northern slopes of the study area have similar dominant directions of asymmetry (Fig. 5b). Strongly and moderate asymmetric basins are located along the eastern and northern border of the High Tatra and southern margins of the Western Tatra Mts. A less defined pattern of Af values can be seen in the Belianskie Tatra, the southern border of the High Tatra, and in the northern slopes of the Western Tatra, with the majority of basins being symmetric or gently asymmetric (Fig. 5a, b).

\section{Basin shape ratio (Bs)}

In the active tectonic areas drainage basins tend to be elongated in shape, normal to the general dip of the area. With continued evolution, or as a result of decreasing tectonic activity, they become more circular in shape (Bull and

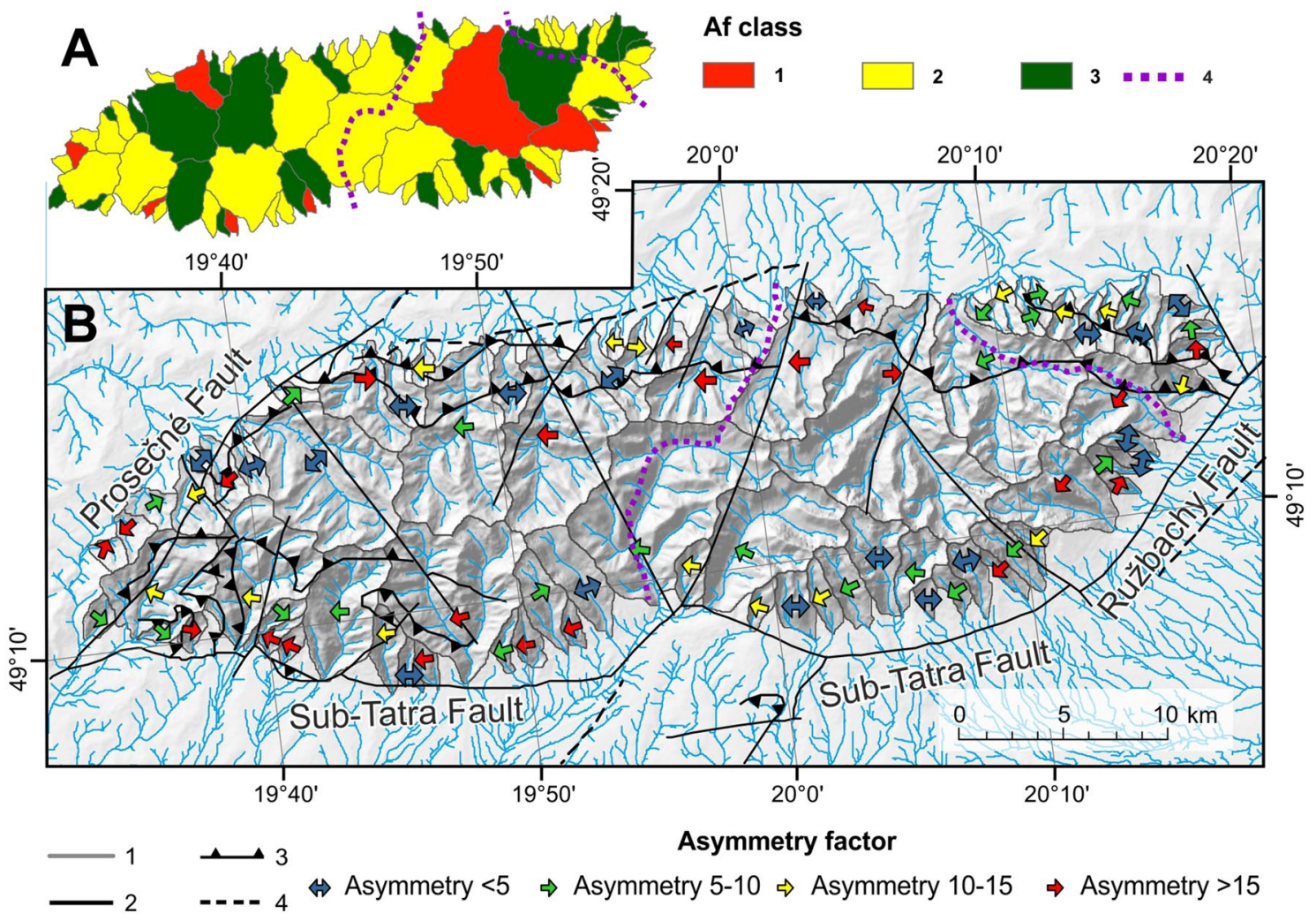

Fig. 5 Asymmetry factor classes in the Tatra Mts.: a absolute values of asymmetry with arrows showing asymmetry sense and colour indicating the value $\mathbf{b}: 1$. Creeks; 2 . faults; 3 . thrusts; 4 . assumed faults.
Dashed lines mark geographic boundaries dividing the Tatra Mountains into three geographic regions 
McFacdden 1977; Ramírez-Herrera 1998; El Hamdouni 2008). Basin shape can be described as the basin shape ratio (Cannon 1976; Ramírez-Herrera 1998):

$\mathrm{Bs}=\mathrm{Bl} / \mathrm{Bw}$,

where $\mathrm{Bl}$ is a maximum length of a basin measured from mouth to the most distant point on drainage divide and $\mathrm{Bw}$ is maximum basin width. According to Chang et al. (2015), Bs values were classified into three classes based on the method of natural breaks: class 1 ( $\mathrm{Bs}>2.9)$, class $2(1.9 \leq \mathrm{Bs} \leq 2.9)$, and class $3(\mathrm{Bs}<1.9)$.

The computation shows that the basin 1 has the lowest Bs value (1.1) and basin 71 has the highest one (4.5) (Fig. 6a). About $76 \%$ of the study area belongs to the 3rd class with nearly circular shapes. Higher values related to elongated basins (classes 1 and 2) appeared in the smaller basins situated next to the mountain fronts of the Tatra Mts. (Fig. 6a).

\section{Hypsometric integral HI}

The hypsometric integral (HI) is a morphometric index which describes the distribution of elevation in a study area (in this case, drainage basins) (Strahler 1952). HI index is dimensionless and is independent of the basin area. Similar to the SL index, rock resistance as well as other factors can affect HI values. High values can indicate possible unstable, active uplifting, young areas. Low values are related with older landscapes which have been more eroded and possibly less affected by tectonic activity (El Hamdouni 2008). This index can be calculated using a simple equation (Pike and Wilson 1971; Mayer 1990):

$\mathrm{HI}=($ mean elevation - min elevation $) /(\max$ elevation - min elevation $)$.

B
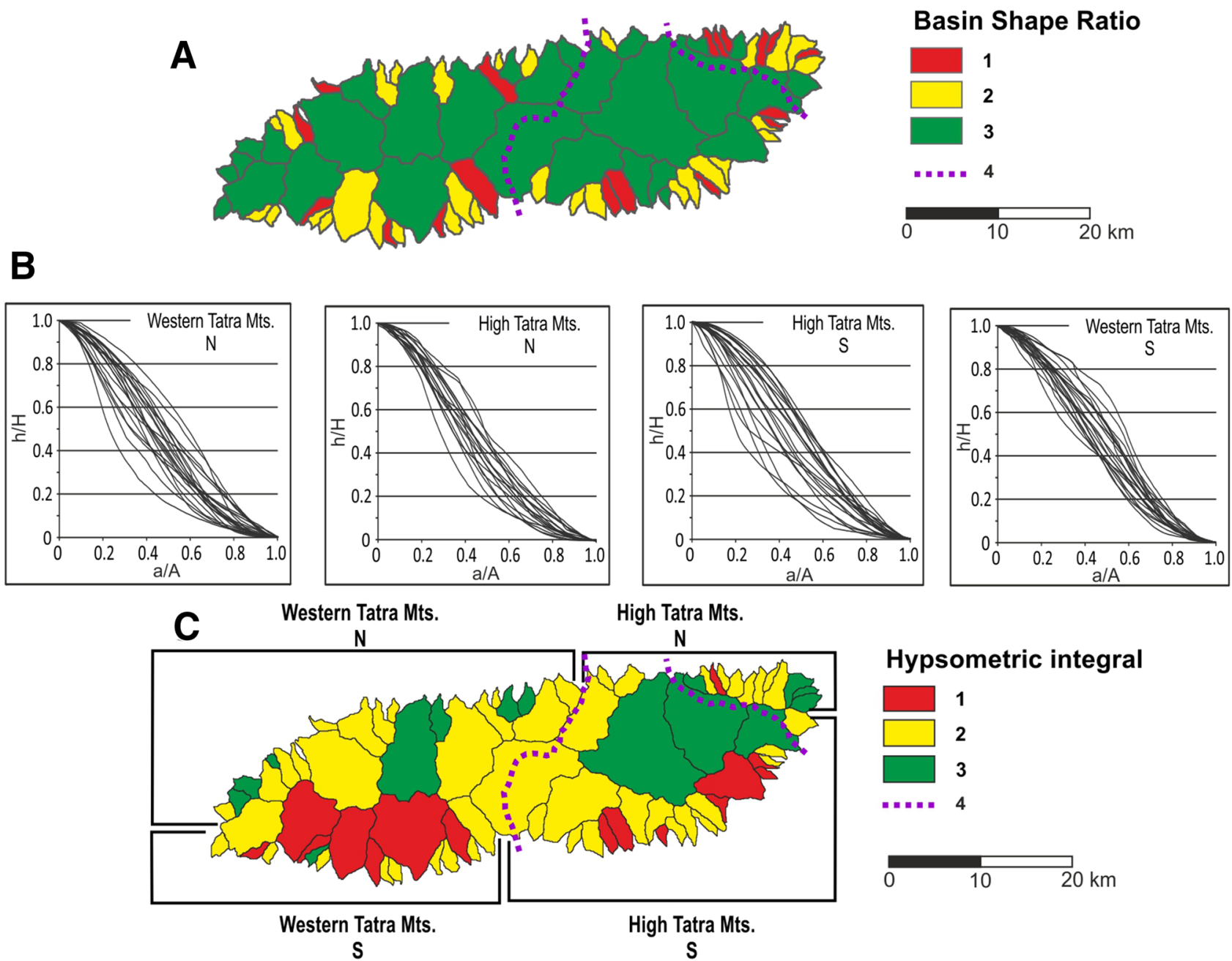

High Tatra Mts.

\section{$\mathrm{N}$}

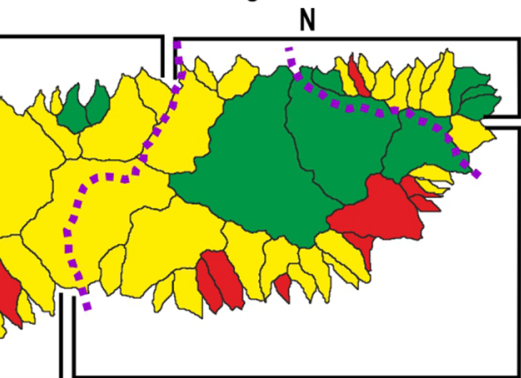

High Tatra Mts.

$S$
Fig. 6 Distribution of the basin shape ratio (Bs) classes in the Tatra Mts. a Hypsometric curves for basins on the northern and southern slopes of the Western and High Tatra Mts. b Distribution of HI classes in study area. c Dashed lines mark geographic boundaries dividing the Tatra Mountains into three geographic regions 
Calculated values of $\mathrm{HI}$ index were classified into three groups: class $1(\mathrm{Hi}>0.5)$, class $2(0.5>\mathrm{Hi}<0.4)$, and class $3(\mathrm{Hi}<0.4)$ (El Hamdouni 2008). In general, the hypsometric integral (HI) represents the area below the hypsometric curve. Shape of the curves varies from convex (class 1), through $\mathrm{S}$-shaped for moderate HI values (class 2 ) to concave shapes for lowest values (class 3 ) (Keller and Pinter 2002; Pérez-Peña et al. 2010).

Hypsometric integral values for each basin ranges from 0.29 (basin 49) to 0.55 (basin 73) (Fig. 6c). The majority of the basins show moderate values of HI with concave-convex hypsometric curves (ca. $58 \%$ of study area). Basins which have been classified into class 1 (ca. $28 \%$ of Tatra Mts.) are located mainly on the southern mountain fronts of the Western and High Tatra Mts. (Fig. 6c). The shape of hypsometric curves shows differences between northern and southern slopes for all the massif, as well as between southern slopes of the Western and High Tatra Mts. (Fig. 6b). The curves from the northern slopes present a more concave shape than the ones from the southern slopes. Furthermore, hypsometric curves of basins located on the southern slopes of the Western Tatra Mts. are slightly more convex than in the High Tatra Mts. (Fig. 6b).

\section{Ratio of valley floor width to valley height (Vf)}

This index discriminates narrow-floored, V-shaped valleys and broad floored, U-shaped valleys. Vf ratio is thought to be a useful proxy for active tectonics due to uplift and it is related to an incision. Low values of $\mathrm{Vf}$ ( $\mathrm{V}$-shaped valleys) are possibly connected with linear incision caused by tectonic uplift. High values of this parameter (U-shaped valley) are related to lateral erosion mainly in response to relative tectonic quiescence. Ratio of valley floor to valley height (Bull and McFadden 1977) is defined as

$\mathrm{Vf}=2 \mathrm{Vfw} /[($ Eld - Esc $)+($ Erd - Esc $)]$

where Vfw is the width of the valley, Eld and Erd are the elevations of left and right divide facing downstream, and Esc is the elevation of valley floor. Usually, the calculation of the Vf is done with a specific distance upstream of a mountain front (Silva et al. 2003). In an area of the Tatra Mts., the distance of $1 \mathrm{~km}$ upstream of the mountain front was used for the measurements.

Measurements of the Vf index were grouped into three categories: $1(\mathrm{Vf} \leq 0.5) ; 2(0.5 \leq \mathrm{Vf}<1)$; and $3(\mathrm{Vf} \geq 1)$ (El Hamdouni, et al. 2008). Values of Vf ranged from 0.14 (basin 36) to 8.69 (basin 13). As we can see in Fig. 7, the

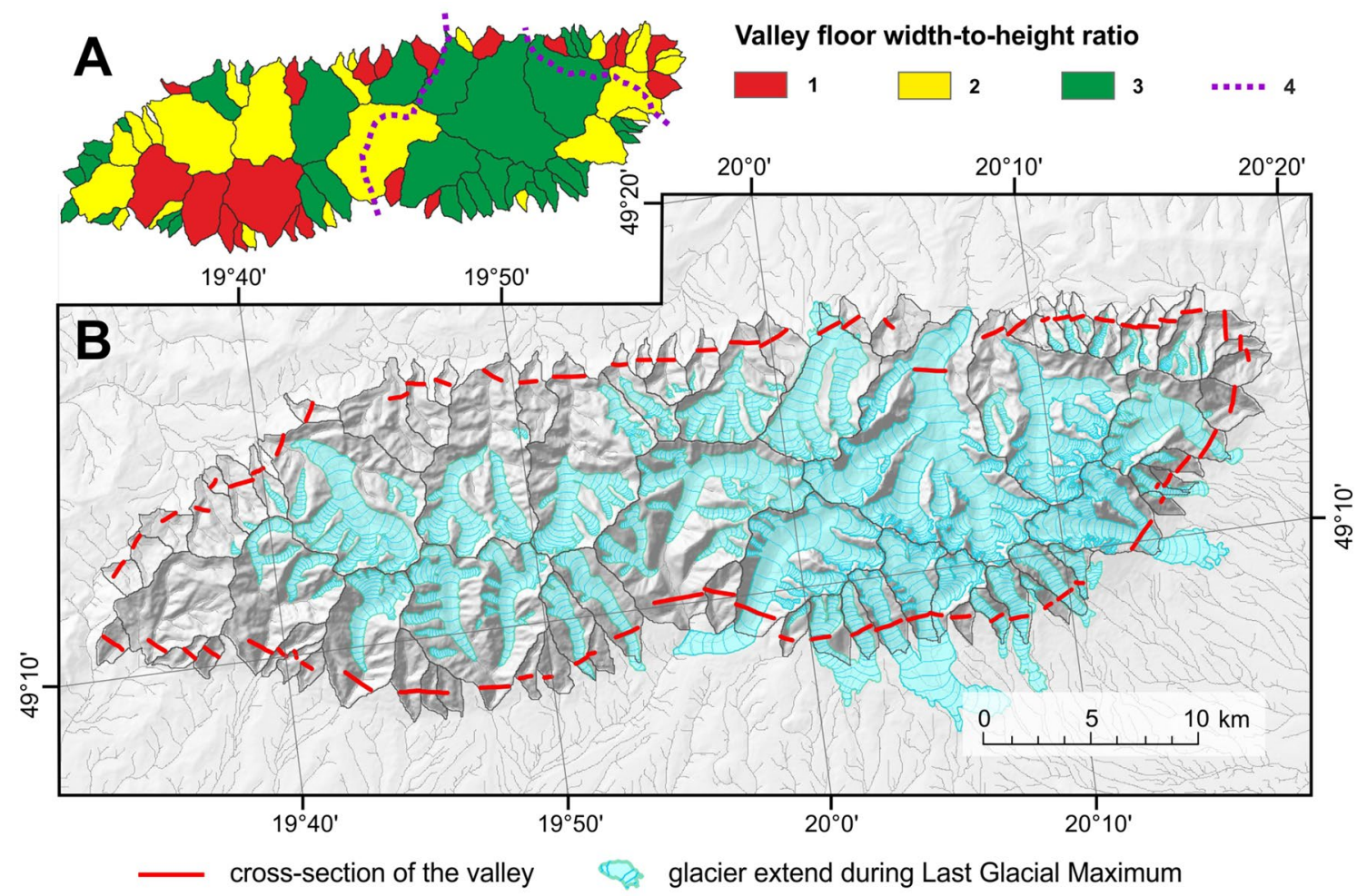

Fig. 7 Classes of the Vf and their distribution (a) in the Tatra Mts. Location of section for the Vf calculation against glacier extends during last glacial maximum (b). Glacier extent after Zasadni and
Kłapyta (2014). Dashed lines mark geographic boundaries dividing the Tatra Mountains into three geographic regions 
majority of basins in the High Tatra Mts. belong to class 3, i.e. relatively shallow valleys. Valleys of the high $\mathrm{Vf}$ values (class 3) are situated along the western front of the Tatra Mts. (Smf V) and southern margins of High Tatra Mts. (Smf III). In turn, a significant number of basins in the Western Tatra Mts. belong to Vf classes 1 and 2. The lowest values of Vf (class 1) are present on the southern slopes of the Western Tatra Mts. as well as on the northern slopes of the High Tatra Mts. (Fig. 7a). According to the obtained Vf values, the majority of the valleys on the study area are U-shaped.

\section{Mountain front sinuosity (Smf)}

Smf index has been often used to evaluate relative tectonic activity along the mountain fronts (Bull and McFadden 1977; Bull 1978; Silva et al. 2003; El Hamdouni et al. 2008). This parameter shows the balance between a tectonic uplift which tends to preserve the straight line of mountain front and river erosion that contributes to creating irregular fronts. Smf is defined as

$\mathrm{Smf}=\mathrm{Lmf} / \mathrm{Ls}$,

where Lmf is a total length of the front along the range-piedmont junction and Ls is a length of a straight line of this front (Bull and McFadden 1977).

Values of Smf were calculated for 7 mountain fronts and sorted into 3 grades: $1(\mathrm{Smf}<1.1) ; 2(1.1 \leq \mathrm{Smf}<1.5)$; and 3 (Smf $\geq 1.5$ ) (El Hamdouni et al. 2008). All mountain fronts around the Tatra massif have a regular, straight shape (1.01-1.08) and belong to class 1 (Fig. 8).

\section{Relative tectonic activity (lat) calculation}

According to El Hamdouni (2008), values of each index were classified into three classes. Average values of six morphometric indices (Af, SL, HI, Bs, Vf, and Smf) were used to evaluate the relative tectonic activity (Iat) of the Tatra Mts. Iat values were divided into four classes: $1-$ very high $(1 \leq$ Iat $<1.5)$, 2 -high $(1.5<$ Iat $<2)$, 3-moderate $(2<$ Iat $<2.5)$, and 4 -low $(2.5<$ Iat $)$ (El Hamdouni et al. 2008).

Approximately $24 \%\left(158.6 \mathrm{~km}^{2}\right)$ of the study area pertains to the second class of relative tectonic activity (Fig. 9). Most parts of the area of the Tatra Mts. (68.4\%) belong to the third class of Iat. Drainage basins which belong to the lowest class of tectonic activity are located mainly along the western margins of the Tatra Mts. (Prosčné fault zone). High values of the index are observed along the southern mountain front, especially in Western Tatra and on the northern margins of the Belianskie Tatra (Fig. 9).

The average value of this index for 78 basins is 1.96 which shows that tectonic activity ranges between high and moderate levels/classes for all of the massif. In the study area, average values of Iat for particular segments show only minor differences: the lowest is for the Western Tatra Mts.

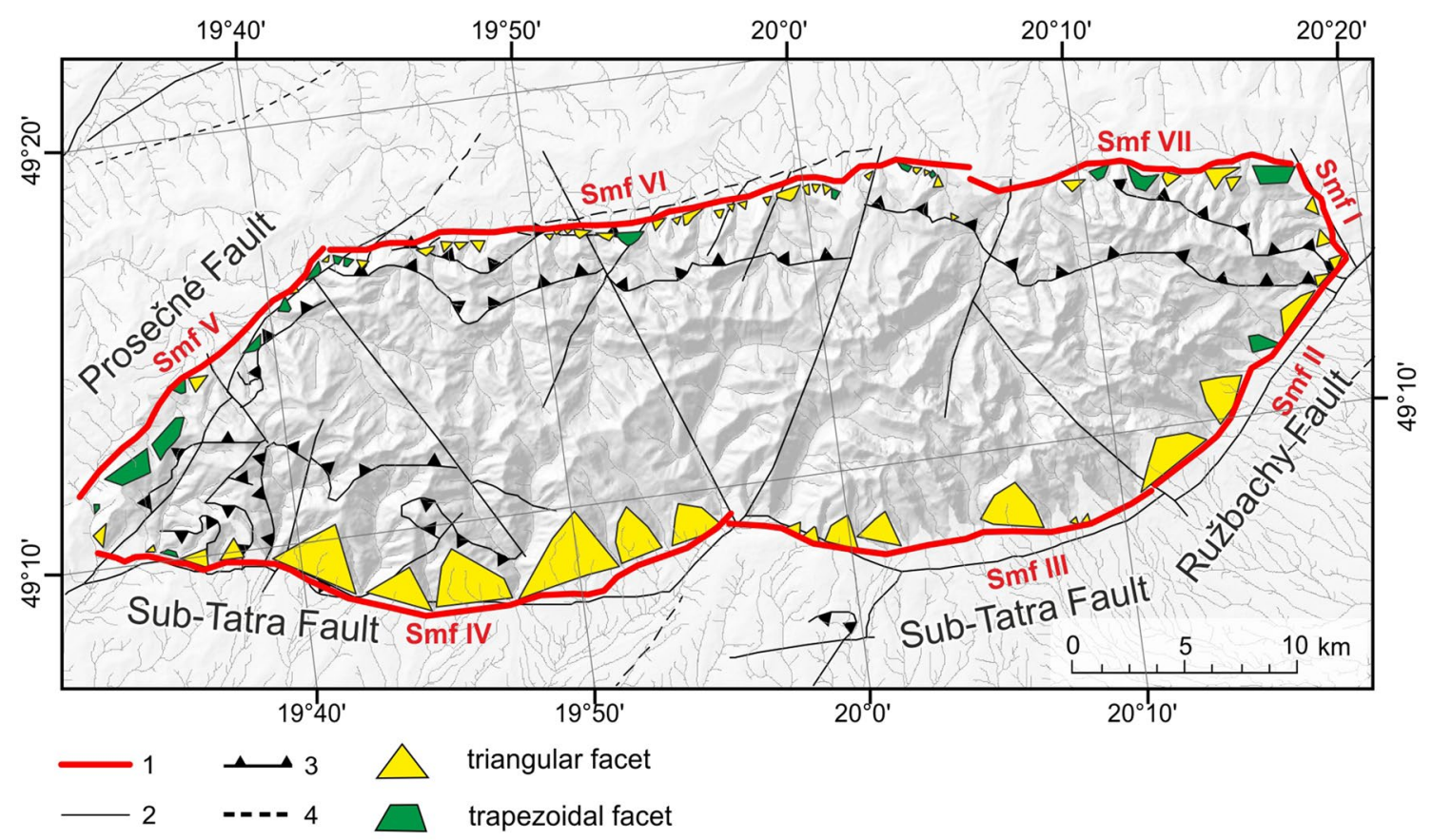

Fig. 8 Location of mountain fronts considered in this study and distribution of the triangular and trapezoidal facets: 1. considered mountain fronts; 2 . faults; 3 . thrusts; 4 . assumed faults 


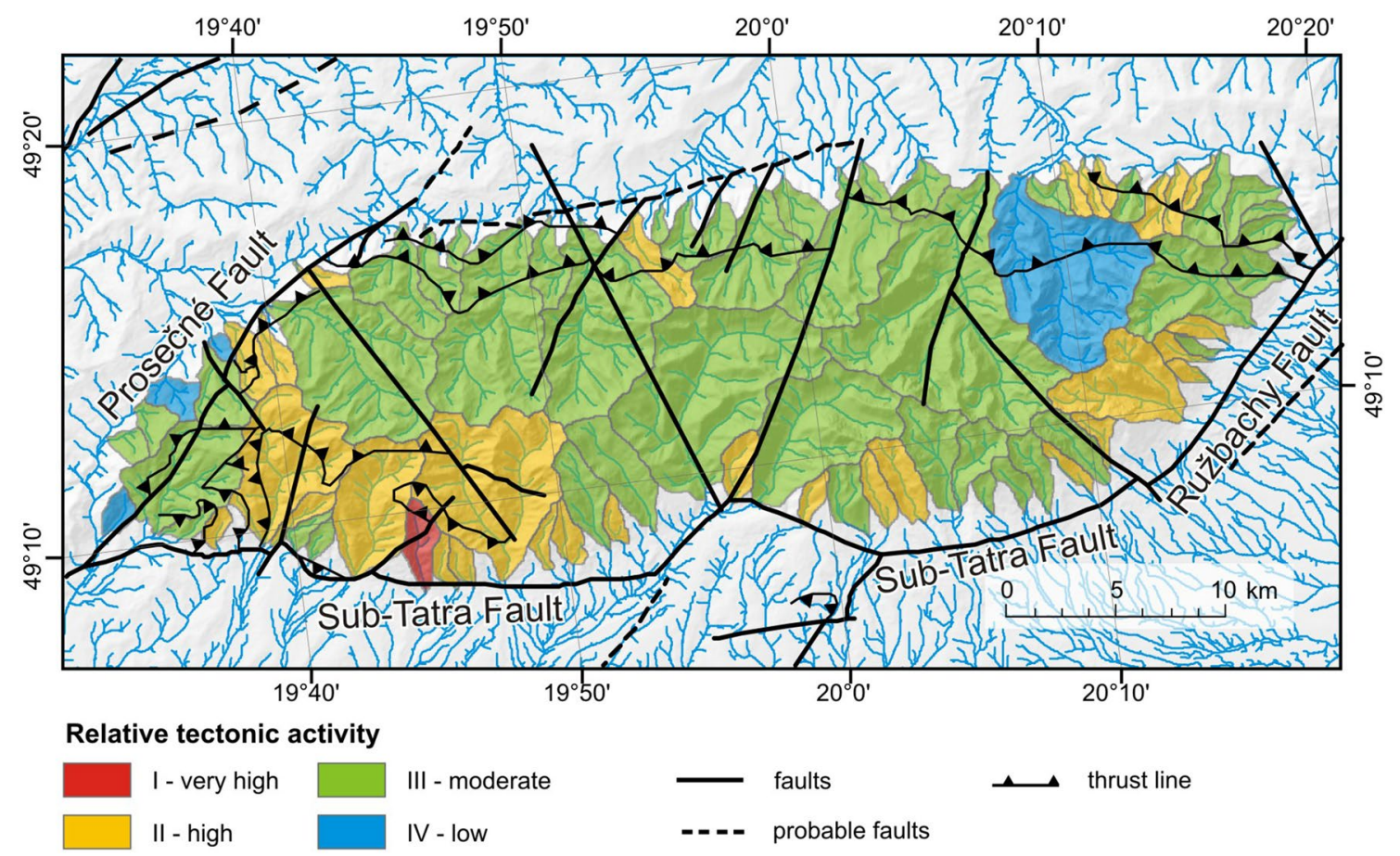

Fig. 9 Distribution of relative tectonic index in Tatra Mts. Tectonic after Lexa et al. (2000)

(1.97), while the highest value reaches for the Belianskie Tatra (1.92). More pronounced differences in Iat values are observed for the basins located on the southern and northern slopes of the massif. Basins on the northern slopes are generally less active (1.84) than on the southern slopes (2.08).

\section{Discussion}

Morphometric analyses can provide valuable clues about tectonic activity especially in areas where only little work on the relation of neotectonic activity and geomorphology is available. Late Quaternary normal faulting in Tatra Mts. was confirmed only by luminescence dating of Vikarovce fault, which is parallel to the Sub-Tatra fault (Vojtko et al. 2011) and U-series datings of speleothems from tectonically deformed caves in Tatra Mts (Szczygieł 2015). Those chronological data points to the acceleration of tectonic uplift since of final phase of Riss Glaciation (Vojtko et al. 2011) or younger (Szczygieł 2015). Mean river incision rates in Tatra Mts. were estimated at $0.2-0.3 \mathrm{~mm} / \mathrm{a}$ for the last $200 \mathrm{ka}$. (Gradziński et al. 2009) or even $\sim 0.5 \mathrm{~mm} / \mathrm{a}$ (Králiková et al. 2014). Average slip rate of Vikarovce normal fault during Late Glacial was estimated at $0.8-1.0 \mathrm{~mm} / \mathrm{a}$ which is similar to other studied faults in Western Carpathians (Vojtko et al. 2011).

The geomorphic indices used in this paper suggested that the Tatra Mts. Are, in general, moderate tectonically active. Almost straight mountain fronts (Smf 1.01-1.08) with well-developed triangular facets (Fig. 9) and wineglass valleys with narrow outlets suggesting active faulting along the mountain massif margins during the neotectonic stage (Zuchiewicz and McCaplin 2000; Burbank and Anderson 2001). According to Wallace (1978), the existence of compound triangular facets indicates several stages of tectonic uplift. The high relative tectonic activity (reflected by pretty high Iat values) in basins along the southern mountain front of the Tatra Mts. (especially the southern front of the Western Tatra Mts.) is probably associated with the tectonic uplift and tilting of the whole massif along the Sub-Tatra fault, as suggested by Piotrowski (1978) and Jurewicz (2005). This uplift along this fault is also confirmed by the highest triangular facets situated along the southern margin of the study area (mountain fronts: Smf II, Smf III, and Smf IV in Fig. 8). In turn, the basins with low Iat values are situated next to the western front (Smf V) of the Tatra Mts. along the Prosčné fault.

Analysis of the Bs index distribution shows that the majority of the Tatra massif is characterized by low tectonic activity. It seems that the values of this parameter depend strongly on the basin area. High and moderate values of the Bs index are characteristic for smaller basins which cut mountain fronts around the Tatra massif. This index is not clearly associated with rock strength (built by rocks that belong to the different rock strength classes). 
Similar to the distribution of the Bs index, V-shaped, deeply incised valleys (1st Vf class) are also connected with smaller basins situated along the northern and southern borders of the massif. Significant decreasing of the Vf values along the southern margins of the High Tatra Mts. (Smf III), and generally on the area of the High Tatra Mts., can be related with the extent of glaciers during the LGM. The majority of glaciers in the High Tatra Mts. have protruded beyond mountain fronts into the foreland (Lukniš 1973; Klimaszewski 1988; Zasadni and Kłapyta 2014). This reshaping of relief possibly caused the difference in the Vf values between the High, Western, and Bialskie Tatra Mts. (Fig. 8). The glaciation asymmetry between northern and southern slopes of the massif was also related to topographic asymmetry caused by northward tilting of the Tatra Mts. (Zasadni et al. 2014). The significant role of glaciers on basin hypsometry, with an example being the Ben Ohau Range in New Zealand, was mentioned by Kirkbride and Matthews (1997). Increasing glacial influence causes a more concave shape of longitudinal profiles and creation of a U-shaped cross-section which is associated with a higher proportion of the basin area at the lower elevation. This influence probably caused a concave shape of hypsometry curves in the valleys on the northern slopes of the High Tatra Mts.

In most cases, high values of the SL index are located in the area of very high rock resistance (granitoid and metamorphic rocks) (Fig. 3). Nonetheless, the appearance of anomalous high values along the Sub-Tatra fault and northern margins of the Belianskie Tatra are accompanied by high values of other proxies. It seems that the extremely low values of this index on the northern margins of the Western Tatra Mts. can be connected both with lower rock resistance and tilting of the whole of the Tatra massif toward the north.

The drainage network in the study area has a radial pattern, with streams generally perpendicular to the main mountain ridge. The asymmetry factor (Af) was calculated to detect large-scale, active tilting. Analysis of basin asymmetry shows a highly diverse and complicated picture. The existence of a large amount of symmetric and gently asymmetric basins is probably related to large-scale tilting of the Tatra Mts. toward the north. However, some strong systematic asymmetry has been found at both sides of main ridge of the massif, which is probably associated with unequal uplift of particular parts of the study area.

\section{Conclusions}

The geomorphic indices calculated in this study suggests that drainage basins in Tatra Mts. may be affected by relatively young tectonic activity and possible uplift with landscape rejuvenation. Almost all indices point to recent tectonic activity of the southern mountain front of this massif, along the Sub-Tatra fault. The distribution of the Iat classes have confirmed the large-scale tilting of the Tatra Mts. toward the north, and associated tectonic uplift along the southern margins of the massif is the prominent activity. Low and moderate Iat values, noticed in some basins along the southern margin of the High Tatra Mts., could be related to the strong glacial reshaping of relief during the Pleistocene. It seems that same indices used in this research (Vf, $\mathrm{Bs}$, and $\mathrm{HI}$ ) are particularly sensitive to glacial reshaping of valley floors (creation of U-shape valleys), as well as large erosion in higher parts of basins.

Acknowledgements This scientific project was supported by the Institute of Nature Conservation Polish Academy of Science (statutory research $\mathrm{nr}$. VI/2)

Open Access This article is licensed under a Creative Commons Attribution 4.0 International License, which permits use, sharing, adaptation, distribution and reproduction in any medium or format, as long as you give appropriate credit to the original author(s) and the source, provide a link to the Creative Commons licence, and indicate if changes were made. The images or other third party material in this article are included in the article's Creative Commons licence, unless indicated otherwise in a credit line to the material. If material is not included in the article's Creative Commons licence and your intended use is not permitted by statutory regulation or exceeds the permitted use, you will need to obtain permission directly from the copyright holder. To view a copy of this licence, visit http://creativecommons.org/licenses/by/4.0/.

\section{References}

Alaei M, Dehbozorgi M, Ghassemi MR, Nozaem R (2017) Evaluation of relative tectonic activity of Buin Zahra-Avaj area, northern Iran. Arab J Geosci 10:229

Arian M, Aram Z (2014) Relative tectonic activity classification in Kermanshah area, west Iran. Solid Earth Discuss 5:2097-2141

Azor A, Keller EA, Yeats RS (2002) Geomorphic indicators of active fold growth: South Mountain-Oak Ridge Ventura basin, southern California. Geol Soc Am Bull 114:745-753

Bac-Moszaszwili M (1995) Diversity of Neogene and Quaternary tectonic movements in Tatra Mountains. Folia Quat 66:131-144

Bagha N, Arian M, Ghorashi M, Pourkermani M, El Hamdouni R, Solgi A (2014) Evaluation of relative tectonic activity in the Tehran basin, central Alborz, northern Iran. Geomorphology 213:66-87

Bishop P (2007) Long-term landscape evolution: linking tectonics and surface processes. Earth Surf Proc Land 32:329-365

Bull WB (1978) Geomorphic Tectonic Classes of the South Front of the San Gabriel Mountains, California. U.S. Geological Survey Contract Report, 14-08-001-G-394, Office of Earthquakes, Volcanoes and Engineering, Menlo Park, CA.

Bull WB (2007) Tectonic geomorphology of mountains: a new approach to paleoseismology. Wiley-Blackwell, Oxford, p 328

Bull WB, McFadden LD (1977) Tectonic geomorphology north and south of the Garlock fault, California. In: Doehring DO (Ed), Geomorphology in Arid Regions. Proceedings of the Eighth Annual Geomorphology Symposium. State University of New York, Binghamton, pp 115-138 
Burbank DW, Anderson RS (2001) Tectonic geomorphology. Blackwell Science, Oxford

Cannon PJ (1976) Generation of explicit parameters for a quantitative geomorphic study of the Mill Creek drainage basin. Okla Geol Notes 36(1):3-16

Chang Z, Sun W, Wang J (2015) Assessment of the relative tectonic activity in the Bailongjiang Basin: insights from DEM-derived geomorphic indices. Environ Earth Sci 74(6):5143-5153

Chen YC, Sung Q, Cheng KY (2003) Along-strike variations of morphotectonic features in the Western Foothills of Taiwan: tectonic implications based on stream gradient and hypsometric analysis. Geomorphology 56:109-137

Dehbozorgi M, Pourkermani M, Arian M, Matkan A, Motamedi H, Hosseiniasl A (2010) Quantitative analysis of relative tectonic activity in the Sarvestan area, central Zagros Iran. Geomorphology 121:329-341

Demoulin A, Beckers A, Hubert-Ferrari A (2015) Patterns of Quaternary uplift of the Corinth rift southern border (N. Peloponnese, Greece) revealed by fluvial landscape morphometry. Geomorphology 246:188-204

Ehsani J, Arian M (2015) Quantitative analysis of relative tectonic activity in the Jarahi- Hendijan basin area, Zagros Iran. Geosci J 19(4):751-765

El-Hamdouni R, Irigaray C, Fernández T, Chacón J, Keller EA (2008) Assessment of relative active tectonics, southwest border of the Sierra Nevada (southern Spain). Geomorphology 96:150-173

Gradziński M, Hercman H, Kicińska D, Barczyk G, Bella P, Holúbek P (2009) Karst of the Tatra Mountains - the development of knowledge in the last thirty years. Przegląd Geologiczny 57:674-684 (in Polish)

Hack JT (1973) Stream-profile analysis and stream-gradient index. J Res US Geol Surv 1:421-429

Hare PW, Gardner TW (1985) Geomorphic indicators of vertical neotectonism along converging plate margins, Nicoya Peninsula, Costa Rica; In: Morisawa M, Hack JT (ed) Tectonic Geomorphology, Proceedings of the 15th Geomorphology Symposium. Birmingham, Allen and Unwinr, Boston, pp 76-104

Hók J, Kysel R, Kováč M, Moczo P, Kristek J, Kristeková M, Šujan M (2016) A seismic source zone model for the seismic hazard assessment of Slovakia. Geol Carpath 67(3):275-290

Hradilec K, Loulova A, Charamza F (1981) Method for determining recent movements of the Earth's crust in high mountain areas. In: Geophysical Syntheses in Czechoslovakia. Veda; Bratislava.

Janák M (1994) Variscan uplift of the crystalline basement, Tatra Mts, Central West Carpathians: evidence from 40Ar/39Ar laser probe dating of biotite and P-T paths. Geol Carpath 45:239-300

Jurewicz E (2005) Geodynamic evolution of the Tatra Mts. and the Pieniny Klippen Belt (Western Carpathians): problems and comments. Acta Geol Pol 55:295-338

Keller EA, Pinter N (2002) Active tectonics: earthquakes, uplift, and landscape. Prentice Hall, New Jersey

Kirkbride M, Matthews D (1997) The role of fluvial and glacial erosion in landscape evolution: The Ben Ohau Range, New Zealand. Earth Surf Proc Land 22:317-327

Kłapyta P, Zasadni J, Pociask-Karteczka J, Gajada A, Franczak P (2016) Late Glacial and Holocene paleoenvironmental records in the Tatra Mountains, East-Central Europe, based on lake, peat bog and colluvial sedimentary data: a summary review. Quat Int 415:126-144

Klimaszewski M (1988) Rzeźba Tatr polskich. PWN, Warsaw, pp $1-668$

Kováč M, Bielik M, Hók J, Kováč P, Labák P, Kronome B, Plašienka D, Šefara J, Šujan M, Moczo P (2002) Seismic activity and neotectonic evolution of the Western Carpathians (Slovakia). In: Neotectonics and surface processes: the Pannonian basin and Alpine/
Carpathian system. EGU Stephan Mueller Spec. Publ. Ser. 3, pp 167-184.

Králiková S, Vojtko R, Sliva U, Minár J, Fügenschuh B, Kováč M, Hók J (2014) Cretaceous-Quaternary tectonic evolution of the Tatra Mts (Western Carpathians): constraints from structural, sedimentary, geomorphological, and fission track data. Geol Carpath 65(4):307-326

Lexa J, Bezák V, Elečko M, Mello J, Polák M, Potfaj M, Vozár J, Schnabel GW, Pálenský P (2000) Geological map of Western Carpathians and adjacent areas 1: 500 000. Geological Survey of Slovak Republic, Bratislava

Łój M, Madej J, Porzucek S, Zuchiewicz W (2009) Monitoring geodynamic processes using geodetic and gravimetric methods: an example from the Western Carpathians (South Poland). Geologia $35: 217-247$

Lukniš M (1973) Relief Vysokych Tatier a ich predpolia (In Slovak). Slov. Akad Vied, Bratislava, p 376

Mahmood SA, Gloaguen R (2012) Appraisal of active tectonics in Hindu Kush: insights from DEM derived geomorphic indices and drainage analysis. Geosci Front 3(4):407-428

Makowska A, Jaroszewski W (1987) On present vertical movements in Tatra Mts and Podhale. Przegląd Geologiczny 35(10):506-512 [In Polish with English summary]

Matoš B, Tomljenović B, Pérez-Peña JV (2016) Landscape response to recent tectonic deformation in the SW Pannonian Basin: evidence from DEM based morphometric analysis of Bilogora Mt. area, NE Croatia. Geomorphology 263:132-155

Mayer L (1990) Introduction to quantitative geomorphology. Prentice Hall, Englewood

Nemčok J, Bezák V, Janák M, Kahan Š, Ryka W, Kohút M, Lehotský I, Wieczorek J, Zelman J, Mello J, Halouzka R, Raczkowski W, Reichwalder P (1993) Explanation to geological map of the Tatra Mts. 1 : 50,000. GÚDŠ, Bratislava (in Slovak).

Ntokos D, Lykoudi E, Rondoyanni T (2016) Geomorphic analysis in areas of low-rate neotectonic deformation: South Epirus (Greece) as a case study. Geomorphology 263:156-169

Pérez-Peña JV, Azor A, Azañón JM, Keller EA (2010) Active tectonics in the Sierra Nevada (Betic Cordillera, SE Spain): Insights from geomorphic indexes and drainage pattern analysis. Geomorphology 119:74-87

Perski Z (2008) Recent tectonic activity of the Tatra Mts and Podhale (Poland) studied by InSAR and PSInSAR. Przegląd Geologiczny 56(12):1082-1086 [In Polish with English summary]

Pike RJ, Wilson SE (1971) Elevation-relief ratio, hypsometric integral and geomorphic area-altitude analysis. Geol Soc Am Bull 82:1079-1084

Piotrowski J (1978) Mesostructural analysis of the main tectonic units of the Tatra Mts. Studia Geologica Polonica 55:1-80 [In Polish with English summary]

Ramírez-Herrera MT (1998) Geomorphic assessment of active tectonics in the Acambay Graben, Mexican volcanic belt. Earth Surf Proc Land 23:317-332

Silva PG, Goy JL, Zazo C, Bardajm T (2003) Fault generated mountain fronts in Southeast Spain: geomorphologic assessment of tectonic and earthquake activity. Gemorphology 250:203-226

Śmigielski M, Sinclair HD, Stuart FM, Persano C, Krzywiec P (2016) Exhumation history of the Tatry Mountains, Western Carpathians, constrained by low-temperature thermochronology. Tectonics $35: 187-207$

Sokołowski S (1959) Geological map of the Nummulitic Eocene Region-Northern Margin of the Polish Tatra. Biuletyn Instytutu Geologicznego 149:197-212 [In Polish]

Strahler AN (1952) Hypsometric (area-altitude) analysis of erosional topography. Geol Soc Am Bull 63:1117-1142 
Szczygieł J (2015) Quaternary faulting in the Tatra Mountains, evidence from cave morphology and fault-slip analysis. Geol Carpath 66(3):245-254

Troiani F, Della Seta M (2008) The use of the stream length-gradient index in morphotectonic analysis of small catchments: a case study from Central Italy. Geomorphology 102:159-168

Vojtko R, Marko F, Preusser F, Madarás J, Kováčová M (2011) Late Quaternary fault activity in the Western Carpathians: evidence from the Vikartovce fault (Slovakia). Geol Carpath 62:563-574

Wallace RE (1978) Geometry and rates of change of fault-generated range fronts, North-Central Nevada. J Res US Geophys Surv $6: 637-650$
Zasadni J, Kłapyta P (2014) The Tatra Mountains during the Last Glacial Maximum. J Maps 10(3):440-456

Zuchiewicz WA, McCaplin JP (2000) Geometry of faceted spurs on an active normal fault: case study of the Central Wasatch Fault, Utah, USA. Ann Soc Geol Pol 70:231-249

Publisher's Note Springer Nature remains neutral with regard to jurisdictional claims in published maps and institutional affiliations. 